\title{
Faye Abdellah Model to Banishing Social Stigma of Head Lice Among School Students
}

\author{
Nehal A. Allam', Wafa A. Al Megrin², Lamya A. Alkeridis ${ }^{2}$ \\ ${ }^{1}$ Department of Pediatric Nursing, Faculty of Nursing, Ain Shams University, Cairo, Egypt \\ ${ }^{2}$ Department of Biology, Faculty of Science, Princes Nourah Bint Abdulrahman University, Al Riyadh, Kingdom of Saudia Arabia
}

Email address:

nehall60@yahoo.com (N. A. Allam)

\section{To cite this article:}

Nehal A. Allam, Wafa A. Al Megrin, Lamya A. Alkeridis. Faye Abdellah Model to Banishing Social Stigma of Head Lice Among School Students. Science Journal of Clinical Medicine. Vol. 5, No. 1, 2016, pp. 1-11. doi: 10.11648/j.sjcm.20160501.11

\begin{abstract}
In this paper, an experimental comparative study was carried out aiming to monitor the effect of Faye Abdellah Theory Model on banishing social stigma of head lice among school students and monitor its effect on their health status and self-esteem. For the study purpose a sample of convenience of 1600 school students and their mothers was recruited from 16 schools from both countries participated in the study. Four tools used, pre/post interviewing questionnaire, observation checklists, Faye Abdellah model format, self-esteem scale sheet and students/mothers guidance booklet. The results showed that the total numbers of students at 8 schools in Egypt were 800/16700, with prevalence ratio 20.8\% and 800/14300 from Kingdom of Saudia Arabia with the prevalence ratio $17.8 \%$. The study documented that there is highly significant effects of the model on students' health status and banishing the social stigma and there is a highly positive association between selfesteem and assurance to the health behavior. It concluded that highly self-esteem had excellent health status and completely confident in coping with self-care management. And it is recommended that knowledge is power and teaching mothers and students about head lice myths and facts is key to demystifying the stigma.
\end{abstract}

Keywords: Head Lice, Social Stigma, Faye Abdellah Theory, School Students, Risk Factors, Self-Esteem

\section{Introduction}

Misinformation about head lice leads to social stigma because of some scare stories make it seem like head lice are in plague proportions and as difficult to eradicate. Which is why so many recoil at the mere mention of the critters. But education and emotional support to the families can be a best weapon [1].

Many people who have been stigmatized, feel as though they are transforming from a whole person to a tainted one [2]. They feel different and devalued by others. Members of stigmatized social groups often face prejudice that causes depression [3]. These stigmas put a person's social identity in threatening situations, like low self-esteem [2].

Head lice represent the most prevalent human parasitic infestation [4]. Head lice is a major problem worldwide, with high rates of infestation in both developed and under developing countries and temperate and tropical areas [5]. Lice have plagued human beings for thousands of years [6]. References to lice appear in the Bible and Egyptian manuscripts dating to the 16 th century BC. Desiccated head lice and eggs have been found on Egyptian and prehistoric North American Indian mummies [7].

Head lice feed on human blood several times a day and live close to the human scalp and spread by direct contact with the hair of an infected person. Spread by contact with clothing (such as hats, scarves, coats) or other personal items (such as combs, brushes, or towels) used by an infected person is uncommon. Personal hygiene or cleanliness in the home or school has nothing to do with getting head lice [8].

Head lice are found worldwide. In the United States, infestation with head lice is most common among pre-school children attending child care, elementary schoolchildren, and the household members of infested children. Although reliable data on how many people in the United States get head lice each year are not available, an estimated 6 million to 12 million infestations occur each year in the United States among children 3 to 11 years of age. In the United States, infestation with head lice is much less common among African-Americans than among persons of other races, possibly because the claws of the of the head louse found most frequently in the United States are better adapted for 
grasping the shape and width of the hair shaft of other races [8]. According to the American Academy of Pediatrics [9] reported that infestations are common among children aged 3 to 12 years. [10] recommended that head lice occur regardless of socioeconomic status or hygienic living conditions and are common in many parts of the world, with an incidence in school children ranging from $2 \%$ to $52 \%$. According to the American Academy of infestations are common among children aged 3 to 12 years.

In Saudi Arabia / Jazan region [11] stated that a total of 114 children (13.3\%) were infested with head lice, 73 $(18.9 \%)$ girls and $41(8.6 \%)$ boys. In the same country, in $\mathrm{Al}$ Riyadh region [12] founded that (12.2\%) 72/590 of students were infected with Pediculosis capitis. In Egypt / Zagazig governorate [13] stated that pediculosis capitis forming the majority $(17.5 \%)$. in Karmouze district, Alexandria, showed that prevalence rate of pediculosis was $58.9 \%$ [14]. This result is lower than the results of [15] who affirm that in primary school children for girls study, the prevalence rate of head lice was $44.2 \%$.

According to faye Abdellah's Twenty-One nursing problems theory of nursing, "Nursing is based on an art and science that molds the attitudes, intellectual competencies, and technical skills of the individual nurse into the desire and ability to help people, sick or well, cope with their health needs." The patient-centered approach to nursing was developed from Abdellah's practice, and the theory is considered a human needs theory. It was created to help with nursing education, so it most applicable in that area. The nursing model is intended to guide care in hospitals, but can be applied to community nursing, as well. The model has interrelated concepts of health and nursing problems, as well as problem-solving, which is an activity inherently logical in nature. Abdellah's theory identifies ten steps to identify the patient's problem and 11 nursing skills used to develop a treatment typology. The ten steps that mentioned in field work. Moreover, the needs of patients are further divided into four categories: basic to all patients, sustenal care needs, remedial care needs, and restorative care needs. [16] [17]

According to (Yoon et al, 2015) [18] who endorsed that, 25 states have head lice populations that are highly resistant to the most commonly used lice shampoo treatments including pyrethrins and the pyrethroid insecticide permethrin. The research work is continuing, but most states tested so far have lice that are resistant to the popular overthe-counter lice treatment options [18]. Studies have examined lotions and other materials (olive oil, butter, mayonnaise, petroleum jelly (Vaseline) that are applied to the head, and then allowed to dry, with the goal of suffocating lice. However, lice are difficult to suffocate; wet-combing probably works as well and is less messy [19]. In the other studies [20] mentioned that petrolatum jelly, mayonnaise, or olive oil may be able to suffocate lice, the lice are still able to close their respiratory spiracles to resist effective penetration of the substance. Some studies say it doesn't really work, but many parents have tried this method with great success.

Although head lice account for a substantial number of missed schooldays in children, among others, it is surprising that these problem is not monitored well in our communities and prevalence is not regularly reported. While we cannot extinguish the parasite, effective monitoring and planning will enable us to limit the occurrence and spreading of this terrible infection.

\subsection{Significance of the Problem}

The social stigma related to head lice has a devastating affect by dividing friends and families, and creating animosity within school environments. This stigma creates a barrier for those who are embarrassed that it stops them from seeking the right treatment and advice for their children. A quick look at the myths and facts can set the record straight, and shift the power differential away from the parasites. On the light of these problems, implementing Faye Abdellah model which will focus on problem solving that will help in humanizing students their mothers and change their perception and increase knowledge, skills to react calmly. Consequently this will empower their self-esteem and confident care practice to attain the highest level of health and attended school regularly.

\subsection{Hypothesis}

Faye Abdellah, 21 nursing problems theory model will to improve school students and their mothers knowledge and practice. Consequently it will empower great self-esteem for practice healthy measures to banishing social stigma of head lice.

\subsection{Aim of the Study}

The study aimed to monitor the effect of Faye Abdellah Theory Model on banishing social stigma of head lice among school students and monitor its effect on their health status and self-esteem through: 1. Determining the prevalence of head lice infestation among primary school students. 2 . Assessing the students and their mothers' knowledge, skills and self-esteem in dealing with associated risk factors of the head lice. 3. Providing the students and their mothers with essential information and skills to overcome their social problems.4. Evaluating the impact of Faye Abdellah Theory Model in relation to health status and banishing social stigma.

\section{Subjects and Methods: (Design, Setting, Subject's)}

Design: An experimental and comparative design was used to conduct the study.

Setting: The study was conducted at the 16 primary schools, eight schools from Egypt, Cairo governorate and eight schools from Kingdom of Saudia Arabia, Al Riyadh region. The schools chosen to represent four sector North, South, West and East per each country. Two schools from each sector was taken. 
Subjects: Total number of girls students from 8 schools at Egypt was $800 / 16700$ with the prevalence ratio was $20.8 \%$. Kingdom of Saudia Arabia, total number of girls from 8 schools was $800 / 14300$, with the prevalence ratio $17.8 \%$. Students chosen by a multi-stage sample. Two stages used to conduct the study. In the first stage, all primary schools were identified. Simple random sampling method was used to choose the two schools from each sector to determine the prevalence of head lice at eight schools. In the second stage, simple and stratified random sampling to choose students to ensure a representative sample of students from all grade levels. The students selected in this sample were extracted using simple random making up a total sample of 100 students from each school from first to sixth grades level. Controls of the study were age of matched students without infection by parasitic infestation.

\subsection{Inclusion Criteria}

Girls Students, age from 6 to 12 years old or more, not suffering from any congenital anomalies or health problems and attended regularly at schools.

\subsection{Tools of Data Collection}

Four tools were designed by the researchers to collect the necessary data, which were:

I. A pre/post Faye Abdellah model interviewing questionnaire: It was developed by the researchers in the light of relevant references to determine the students and their mothers knowledge and social problems. It was written in a simple Arabic language, its content validity was assessed and secured by expert consultants from the pediatric nursing, and parasitology departments. The interviewing questionnaire includes 2 main parts:

Part 1: This part was used to gather demographic data such as age, grade, education level, duration of infection, recurrence, mothers education, labor condition, and number of family members'.

Part 2: It is concerned with a) students and their mothers knowledge regarding morphology of lice, mode of transmission, risk factors, clinical manifestations, preventive measures, needed care, treatment used and previous number of infestation with head lice and role of school health nurse in detection, treatment, and control of head lice infestation. b)Psychological social problems of the students and her mother's concerning disease as denial, anger, anxiety, depression, disappointment, withdrawal and measures used to overcome its.

Questions were in the form of close- open-ended questions and the total number of questions was 30 . Scoring system for students' scores was as follows: $>75$, Good; 50-75, Average; and $<50$ Poor.

II. A pre/post Faye Abdellah model Observation checklist for visual inspection of the students scalp:

The researchers designed it to check the student scalp for presence of lice and or nits, length of hair and cleaning of the hair.

Abdellah's 21 nursing problem framework: The researchers modified it to organize students care needs/problems in a model similar to Maslow's hierarchy of needs, addressing basic (fundamental to all) to the restorative (higher level) care needs. Basic Care Needs (1 - 4), Level 2 - Sustenal Care Needs (5-11), Level 3- Remedial Care Needs (12-18) and Level 4 - Restorative Care Needs (19-21) as showed in table (3) \%(4).

III. State Self-Esteem Scale The State Self-Esteem scale (SSES: Heatherton \% Polivy, 1991) [21] This is a commonly used to measure students' self-esteem. The scale consists of 20 items questionnaire that tap momentary fluctuations in self-esteem. The scale as illustrated in table (5). The decision to use it depends on whether one is interested in predicting long-term outcomes or in the immediate effects associated with feelings about the self. There is, of course, no right answer for any statement. The best answer is what the students feel is true at certain moment. Answer the questions as they are true for students feeling right now. $1=$ not at all $2=$ a little bit $3=$ somewhat $4=$ very much $5=$ extremely

IV. Children/parents guidance booklet: It was designed by the researchers to supply the students and their mothers with essential information about head lice, mode of transmission prevention and measures to overcome the environmental risk factors. Also procedures steps for licid or mayonnaise application was explained in details to let them apply at home smoothly.

\subsection{Content Validity}

The validity of the study tools and the booklet guidelines was done through nine experienced professionals, 5 experts from pediatric nursing department', as well as 3 from epidemiology medicine department and 1 from psychiatric nursing department, they reviewed the materials for comprehensiveness and relatedness. After rigorous revision by the experts, the tool and guidelines were finalized based on their recommendations.

\subsection{Pilot Study}

This was carried out to test the feasibility and practicability of the study tools on 80 students and their mothers, 40 from each country representing $10 \%$ of the total study sample and to measure an estimate of the time needed to fill out the tools. The pilot subjects were later excluded from the study sample. According to the pilot study results, the necessary modifications were done.

\subsubsection{Administrative Design and Ethical Considerations}

An official permission was obtained from the directors of training and development at the Ministry of Education, Health Unit and schools principles to conduct the study. The aim of the study and procedures were explained to subjects to attain their cooperation. A written informed consent was 
obtained from the students and their mothers to ensure willingness to engage in the study after explaining its purpose. They were informed about their rights to withdraw at any time with no consequences on their care. The study interventions could not have any harmful effect. Confidentiality of the information was ensured. Ethical clearance were addressed by treating positive students using standard drugs under school medical supervision and nurses.

\subsubsection{Field Work}

This study was conducted during the academic year 20122013.

Faye Abdellah Model was carried out on 4 phases namely:

I. Assessment Phase of Faye Abdellah model: The researchers specified 2 months for each Country to collect data about the subjects by interviewing them on Sunday and Monday weekly (for 8 weeks) at the schools time (8.00 a.m. -1.00 p.m.). Students and their mothers were interviewed to determine their social stigma and perception about head lice and its management using a pre/post Faye Abdellah model interviewing questionnaire and State Self-Esteem Scale. The researchers assess the students health needs for managing head lice as problems, which was overt, or covert as well. The interview results showed that the subjects problems was emotional, sociological, and interpersonal in nature, they perceived incorrectly before intervention. Researchers was forceful to create trusting relationships with students and their mothers and tried to understand social stigma problems facing them at school and home. The researchers followed the ten steps of Faye Abdellah model as 1. Learn to know the students, 2 . Sort out relevant and significant data about the students, 3. Make generalizations about available data in relation to problems, 4 Identify the therapeutic plan, asked them which treatment they used, 5. Test generalizations with the students and make additional generalizations for any details, 6. Validate the students conclusions about the head lice, 7. Continue to observe and evaluate the patient over a period of time to identify any attitudes and clues affecting his or her behavior through the interview, 8. Explore the students and her mother's reactions to the therapeutic plan and involve them in the plan, 9. Identify researchers feeling about the students problems problems. 10. Discuss and develop a comprehensive nursing care plan. Assess the students emotional problems by 10 question of State Self-Esteem Scale as in table (5).

II. Planning Phase of Faye Abdellah Model: The researchers assigned one month for 16 school to plan the requirements of students and their mothers. As Abdellah's work is a set of problems formulated in terms of nursing-centered services, which are used to determine the student's needs. The nursing-centered orientation as model to students care to provide support. This done by nursing practice to for restorative process of self-esteem and preventive measures for head lice. The researchers planned for the problem-solving process involves steps as identifying the problem, selecting pertinent data, formulating hypotheses, testing hypotheses through the collection of data, and revising hypotheses when necessary on the basis of conclusions obtained from the data. The researchers formulated the nursing diagnosis, then nursing care plan is developed and appropriate nursing interventions are determined according their needs.

III. Implementation Phase of Faye Abdellah Model: The researchers allocated 7 months to contract the students use of the services offered, practice of professional assistance for problem solving alternatives based on Abdellah's 21 nursing problem frame work and modified according to the children and their parents needs and problems

Level 1: Basic Care Needs (1-4) - The researchers identified all students problems by direct or indirect methods. 1. To maintain good hygiene and physical comfort of students. 2. To promote optimal activity: exercise, rest, and sleep. 3. To promote safety through the prevention of the spread of infection of head lice. 4. To maintain good body mechanics and prevent and correct deformities. Modified by maintain interaction with other students and plying with them.

Level 2- Sustenal Care Needs (5-11) - Usually overt problems, identified through direct approach. 5. To facilitate the maintenance of a supply of oxygen to all body cells through environmental sanitation. 6. To facilitate the maintenance of nutrition of all body cell through good nutrition. 7. To facilitate the maintenance of elimination. 8. To facilitate the maintenance of fluid and electrolyte balance. 9. To recognize the physiological responses of the body to disease conditions. 10. To facilitate the maintenance of regulatory mechanisms and functions. 11. To facilitate the maintenance of sensory functions

Level 3- Remedial Care Needs (12-18) - Usually covert problems- was with emotional \% interpersonal difficulties identified through indirect approach - 12. To identify and accept positive and negative expressions, feelings, and reactions as social stigma of head lice. 13. To identify and accept the interrelatedness of emotions and organic illness. 14. To facilitate the maintenance of effective verbal and nonverbal communication. The researchers encourage students to tell all emotional problems facing them at schools, with teachers with friends. 15. To promote the development of productive interpersonal relationships. The researchers hearten students to deal with others and lice can infect any one at any time 16 . To facilitate progress toward achievement of personal spiritual goals. The researchers requested them to attend at school regularly without any embarrassments and receive treatment to avoid poor academic achieviements. 17. To create and/or maintain a therapeutic environment. 18. To facilitate awareness of self 
as an individual with varying physical, emotional, and developmental needs. A total of 1600 students from the selected primary schools were examined for the presence of head lice using faye Abdellah model Observation checklist.

The researchers divided the students randomly into 2 groups at each country. Group (1) was for the girls who applied mayonnaise and group (2) for girls who applied Licid shampoo. During examination the researchers wearing coat and gloves, then screening of each student scalp was done by visual examination by naked eyes in sufficient day light, using fine small wood to separate the hair. When found the eggs, nymph or adult lice. The researchers used a magnifying glass to confirm the diagnosis. The researchers gave attention to the students hair cleanliness and length of hair were also assessed. The student was considered as positive of head lice infection if there was any evidence of head lice, such as detected head lice or nymphs, and live or dead eggs. The screening was done by the researchers with assistance of school nurses in Egypt and social workers in Kingdom of Saudia Arabia. After finishing data collection, the students were informed about the problems in an ethical manner and asked them to bring their mothers, or contacted her or send letters with students. The students divided into 4 groups randomly. One groups for each country received mayonnaise and other one received licid shampoo. After discussion with students and their mothers in a private room or in a principle office, their written agreement was taken to apply either mayonnaise or licid shampoo. Demonstrate for mothers how she can apply the treatment to their students at home done by using a manikin as a model and a booklet containing general information about head lice, steps of applying either mayonnaise or licid shampoo was given to every student mothers. Students are challenged to keep to therapy schedule without embarrassments. After 5 to 6 days, the researchers, school nurses and social workers monitor the students again to ensure from effectiveness of application and follow them until complete recovery. The researchers allocated 10 hours for each school to cover the theoretical and practical part. Theoretical sessions was about (Head lice, causes, manifestations, care measures, preventive measures, environmental sanitation, way of treatment application and way to overcome social stigma. In addition to the complications and managements, importance of investigations every week and follow up -Teaching methods used were lectures, group discussions, demonstrations, a comic book, drawing activities and role play while the instruction media used were colored posters, transparencies, handouts and blackboard. The researchers took into consideration the students level of understanding, motivation and reinforcement techniques as praise to enhance learning.

IV. Evaluation Phase of Faye Abdellah Model:

The researchers allocated one months for each country to evaluate the students and their mothers concerning dealing with social stigma, school troubles, needs, problem of lice and ensure that they no longer needs professional services and gives up dependent behavior with high self-esteem. Accordingly, the score was given according their level of achievements. The model, Level 4 - Restorative Care Needs (19-21) Overt or covert problems. Students problems identified through direct or indirect approach19. To accept the optimum possible goals in the light of limitations, physical and emotional. After intervention the students identified the problem well and how to cope with it selfconfidence and self-esteem. 20. To use community resources as an aid in resolving problems arising from illness. Students asked help without embarrassment. 21. To understand the role of social problems as influencing factors in the case of illness. They reported that the problem understood, they promise to give attention to continuous check. Evaluate the effects of the model on banishing social stigma of head lice and students health status, coping abilities with high selfesteem carried out using the same tools of assessment phase immediately after the program implementation.

\subsection{Statistical Analysis and Results}

The collected data were coded, analyzed and tabulated using mean, standard deviation \% chi-square tests and using SPSS ver. 20.

Table 1. Distribution of Some Demographic Data of Students in Both settings Egypt\% Kingdom of Saudia Arabia (800 students/Country).

\begin{tabular}{|c|c|c|c|c|}
\hline \multirow{3}{*}{ Age group (in years) } & \multicolumn{2}{|c|}{ Egypt Girls N=800 } & \multicolumn{2}{|c|}{ Kingdom of Saudia Arabia $N=800$} \\
\hline & \multicolumn{2}{|c|}{ Girls } & \multicolumn{2}{|c|}{ Girls } \\
\hline & No & (\%) & No & (\%) \\
\hline 6-8 Grade Level $1^{\text {st }} \& 2^{\text {nd }}$ & 422 & $(52.75)$ & 268 & $(33.50)$ \\
\hline $8-10$ Grade Level3 $3^{\text {rd } \%} 4^{\text {th }}$ & 266 & $(33.25)$ & 440 & $(55.00)$ \\
\hline$\geq 12$ Grade Level $5^{\text {th }} \% 6^{\text {th }}$ & 112 & $(14.00)$ & 92 & $(11.50)$ \\
\hline Mean and $S D$ & 7.7 & & 8.56 & \\
\hline \multicolumn{5}{|l|}{ Family Size } \\
\hline $1-2$ & 230 & $(28.75)$ & 188 & $(23.5)$ \\
\hline $2-4$ & 485 & $(60.63)$ & 266 & $(33.25)$ \\
\hline$\geq 5$ & 85 & $(10.62)$ & 346 & $(43.25)$ \\
\hline \multicolumn{5}{|l|}{ Mother Education } \\
\hline Educated & 633 & (79.13) & 592 & (74.00) \\
\hline Uneducated & 167 & (20.87) & 208 & $(26.00)$ \\
\hline \multicolumn{5}{|l|}{ Mother Job } \\
\hline Employed & 712 & $(89.00)$ & 462 & $(57.75)$ \\
\hline Un employed & 88 & $(11.00)$ & 338 & $(42.25)$ \\
\hline
\end{tabular}


Table (1) showed that the prevalence of head lice among study girls students was common in Egypt in Grade Level $1^{\text {st }} \%$ 2nd and aged ranged from 6 to 8 years where more than half (52.75\%) of girls were infected. In Saudia Arabia, the prevalence was common among girls students in Grade Level $3^{\text {rd }} \% 4^{\text {th }}$ and their aged ranged from 8 to 10 years, more than half $(55.0 \%)$ of girls were infected. Moreover, about (43.25\%) of the families in Saudia Arabia having more than 5 children as compared to $(10.62 \%)$ in Egypt.

Table 2. Relationship Between School Students Age, Hair Examination Results, Recurrence, Risk Factors and Treatment Used.

\begin{tabular}{|c|c|c|c|c|c|c|c|c|c|c|c|c|}
\hline \multirow{3}{*}{ Age group (in years) } & \multicolumn{6}{|c|}{ Egypt $\mathbf{N}=\mathbf{8 0 0}$} & \multicolumn{6}{|c|}{ Kingdom of Saudia Arabia $\mathbf{N}=\mathbf{8 0 0}$} \\
\hline & \multirow{2}{*}{\multicolumn{2}{|c|}{$\begin{array}{l}\text { 6-8 years } \\
(n=422) \\
\end{array}$}} & \multirow{2}{*}{\multicolumn{2}{|c|}{$\begin{array}{l}\text { 8-10 years } \\
(n=266)\end{array}$}} & \multirow{2}{*}{\multicolumn{2}{|c|}{$\begin{array}{l}\geq 12 \text { years } \\
(n=112)\end{array}$}} & \multirow{2}{*}{\multicolumn{2}{|c|}{$\begin{array}{l}\text { 6-8 years } \\
(n=268)\end{array}$}} & \multirow{2}{*}{\multicolumn{2}{|c|}{$\begin{array}{l}\text { 8-10 years } \\
(n=440)\end{array}$}} & \multirow{2}{*}{\multicolumn{2}{|c|}{$\begin{array}{l}\geq 12 \text { years } \\
(n=92)\end{array}$}} \\
\hline & & & & & & & & & & & & \\
\hline \multicolumn{13}{|l|}{ Hair length } \\
\hline Short $<5 \mathrm{~cm}$ & 87 & $(20.6)$ & 17 & $(6.4)$ & 22 & $(19.6)$ & 34 & $(12.7)$ & 86 & $(19.5)$ & 38 & $(41.3)$ \\
\hline Medium $(5 \mathrm{~cm}-15 \mathrm{~cm})$ & 250 & $(59.2)$ & 87 & $(32.7)$ & 44 & $(39.3)$ & 66 & $(24.6)$ & 116 & $(26.4)$ & 12 & $(13.0)$ \\
\hline Long $>20 \mathrm{~cm}$ & 85 & $(20.2)$ & 162 & $(60.9)$ & 46 & $(41.1)$ & 168 & $(62.7)$ & 238 & $(54.1)$ & 42 & $(45.7)$ \\
\hline \multicolumn{13}{|l|}{ No of repeated infection } \\
\hline First Time & 92 & $(21.8)$ & 66 & $(24.8)$ & 0 & $(00.0)$ & 43 & $(16.0)$ & 132 & $(30.0)$ & 0 & $(00.0)$ \\
\hline $2-3$ & 330 & $(78.2)$ & 89 & $(39.4)$ & 102 & $(91.1)$ & 143 & $(53.4)$ & 242 & $(55.0)$ & 23 & $(25.0)$ \\
\hline More than 3 & 0 & $(00.0)$ & 111 & $(41.7)$ & 10 & $(8.9)$ & 82 & $(30.6)$ & 66 & $(15.0)$ & 69 & $(75.0)$ \\
\hline \multicolumn{13}{|l|}{ Risk Factors } \\
\hline Sharing hair combs or brush & 320 & $(75.8)$ & 36 & $(13.5)$ & 0 & $(00.0)$ & 215 & $(80.2)$ & 126 & $(28.6)$ & 0 & $(00.0)$ \\
\hline Using towels with others & 112 & $(26.5)$ & 18 & $(6.8)$ & 0 & $(00.0)$ & 233 & $(86.9)$ & 218 & $(49.5)$ & 0 & $(00.0)$ \\
\hline Sharing head covers & 325 & $(77.0)$ & 10 & $(3.8)$ & 0 & $(00.0)$ & 239 & $(89.2)$ & 273 & $(62.0)$ & 0 & $(00.0)$ \\
\hline \multicolumn{13}{|l|}{ Treatment Used } \\
\hline Licid Lotion & 386 & $(91.5)$ & 178 & $(66.9)$ & 88 & $(66.9)$ & 218 & $(81.3)$ & 312 & $(70.9)$ & 67 & (72.8) \\
\hline Kerosene & 225 & (53.3) & 108 & $(47.8)$ & 25 & $(22.3)$ & 0 & $(00.0)$ & 0 & $(00.0)$ & 0 & $(00.0)$ \\
\hline Petroleum jelly & 77 & $(18.2)$ & 180 & $(79.6)$ & 12 & $(10.7)$ & 88 & $(32.8)$ & 289 & $(65.7)$ & 75 & $(81.5)$ \\
\hline Vinegar & 68 & $(16.1)$ & 78 & $(29.3)$ & 19 & $(17.0)$ & 156 & $(58.2)$ & 290 & (65.9) & 82 & $(89.1)$ \\
\hline Olive Oil & 33 & $(7.8)$ & 12 & $(4.5)$ & 7 & $(6.3)$ & 104 & $(38.8)$ & 336 & (76.4) & 92 & (100.0) \\
\hline
\end{tabular}

As displayed in table (2) The hair length among students in Saudia Arabia more longer as compared to students in Egypt, where more than two third $(62.7 \%)$ of students, from $6-8$ years their hair length was more than $20 \mathrm{~cm}$ as compared to $(20.2 \%)$ in Egypt. The table showed the repeated infection for 2 to 3 times was common (78.2\%) in Egypt among youngest students from 6 to 8 years and $(91.1 \%)$ among $\geq 12$ years students. In Saudia Arabia, the recurrence of infection was common between students at 8 to 10 years and $\geq 12$ years where $(55.0 \%)$ and (75.0) were infected respectively. The risk factors was few among $\geq 12$ years students in both settings. The table convey that most of mothers in both settings used Licid Lotion as a treatment to overcome the head lice. Amazing In Saudia Arabia none of the mothers used Kerosene as head lice treatment as compared to (53.3\%) $(47.8 \%)(22.3 \%)$ respectively in Egypt. **Number are not exclusive for risk factors and treatment used

Table 3. Distribution of School Students and Their Mothers Knowledge About Head Lice Pre/Post Application of Faye Abdellah Model at Egypt.

\begin{tabular}{|c|c|c|c|c|c|c|c|}
\hline \multirow[b]{2}{*}{ Faye Abdellah Levels } & \multicolumn{3}{|c|}{ Pre $(n=800)$} & \multicolumn{3}{|c|}{ Post $(\mathrm{n}=\mathbf{8 0 0})$} & \multirow[b]{2}{*}{$\begin{array}{l}\text { Chi-square } \\
\text { t \%p-value }\end{array}$} \\
\hline & $\begin{array}{l}\text { Poor No } \\
\text { (\%) }\end{array}$ & $\begin{array}{l}\text { Average } \\
\text { No (\%) }\end{array}$ & $\begin{array}{l}\text { V. Good } \\
\text { No (\%) }\end{array}$ & $\begin{array}{l}\text { Poor No } \\
\text { (\%) }\end{array}$ & $\begin{array}{l}\text { Average } \\
\text { No (\%) }\end{array}$ & $\begin{array}{l}\text { V. Good } \\
\text { No (\%) }\end{array}$ & \\
\hline Level 1: Basic Care Needs (\#1-4) & 230 & 455 & 115 & 83 & 75 & 642 & $\mathrm{p}<0.001$ \\
\hline Knowledge about head lice & & & & & & & \\
\hline Morphology of lice & & & & & & & \\
\hline $\begin{array}{l}\text { Mode of transmission Clinical manifestation- Way of } \\
\text { diagnosis }\end{array}$ & $(28.7)$ & $(56.9)$ & (14.4) & $(10.4)$ & (9.4) & $(80.2)$ & \\
\hline Control Measures & & & & & & & \\
\hline $\begin{array}{l}\text { Good hygiene and physical comfort } \\
\text { Prevention measures -Interaction with other children. }\end{array}$ & & & & & & & \\
\hline$X \pm S D$ & & $60.1 \pm 2.4$ & & & $80.0 \pm 6$. & & \\
\hline Level 2 - Sustenal Care Environmental sanitation. & 180 & 520 & 100 & 12 & 120 & 668 & $\mathrm{p}<0.001$ \\
\hline $\begin{array}{l}\text { Proper nutrition and fluids Hair Care - Control } \\
\text { Measures }\end{array}$ & $(22.5)$ & $(65.0)$ & $(12.5)$ & $(1.5)$ & $(15.0)$ & $(83.5)$ & \\
\hline$X \pm S D$ & & $61.5 \pm 3.1$ & & & $83.0 \pm 6.8$ & & \\
\hline
\end{tabular}




\begin{tabular}{|c|c|c|c|c|c|c|c|}
\hline \multirow[b]{2}{*}{ Faye Abdellah Levels } & \multicolumn{3}{|c|}{ Pre $(n=800)$} & \multicolumn{3}{|c|}{ Post $(n=800)$} & \multirow{2}{*}{$\begin{array}{l}\text { Chi-square } \\
\text { t \%p-value }\end{array}$} \\
\hline & $\begin{array}{l}\text { Poor No } \\
(\%)\end{array}$ & $\begin{array}{l}\text { Average } \\
\text { No }(\%) \\
\end{array}$ & $\begin{array}{l}\text { V. Good } \\
\text { No (\%) } \\
\end{array}$ & $\begin{array}{l}\text { Poor No } \\
(\%)\end{array}$ & $\begin{array}{l}\text { Average } \\
\text { No }(\%) \\
\end{array}$ & $\begin{array}{l}\text { V. Good } \\
\text { No }(\%) \\
\end{array}$ & \\
\hline $\begin{array}{l}\text { Level 3- Remedial Care } \\
\text { Emotional Problems solving } \\
\text { as social stigma of head lice } \\
\text { Facilitate effective communication } \\
\text { Attend at school regularly Receive treatment - } \\
\text { Develop a trusting and therapeutic relationship }\end{array}$ & $(56.5)$ & $(40.6)$ & $(2.9)$ & $(6.9)$ & $(10.7)$ & $(82.4)$ & $\mathrm{p}<0.001$ \\
\hline$X \pm S D$ & & $49.8 \pm 2.9$ & & & $81.2 \pm 6.3$ & & \\
\hline $\begin{array}{l}\text { Level 4- Restorative Care } \\
\text { Resolving problems arising from illness. Follow up } \\
X \pm S D\end{array}$ & $\begin{array}{l}333 \\
(41.6)\end{array}$ & $\begin{array}{l}167 \\
(20.9) \\
\mathbf{6 1 . 6} \pm \mathbf{4 . 1}\end{array}$ & $\begin{array}{l}300 \\
(37.5)\end{array}$ & $\begin{array}{l}102 \\
(12.8)\end{array}$ & $\begin{array}{l}129 \\
(16.1) \\
\mathbf{7 7 . 1} \pm \mathbf{2 . 4}\end{array}$ & $\begin{array}{l}569 \\
(71.1)\end{array}$ & $\mathrm{P}>0.05$ \\
\hline
\end{tabular}

Table (3) reveal The effects of pre/post application of Faye Abdellah Model on students and their mothers in terms of knowledge and care. There was highly significant statistically significant differences $(\mathrm{p}<0.001)$, concerning knowledge of the sample about head lice in Egypt between pre/post application of the model, regarding all levels of Faye model $(\mathrm{p}>0.001)$ except restorative care level was insignificant
$(\mathrm{P}>0.05)$. Approximately $(14.4 \%)$ in basic needs level got very good rank pre intervention as compared to $(80.2 \%)$ post intervention. Regarding sustenal care only $(12.5 \%)$ of students and their mothers scored high level pre intervention as compared to $(83.5 \%)$, who scored high post intervention and same for all levels.

Table 4. Distribution of School Students and Their Mothers Knowledge About Head Lice Pre/Post Application of Faye Abdellah Model at Kingdom of Saudia Arabia.

\begin{tabular}{|c|c|c|c|c|c|c|c|}
\hline \multirow[b]{2}{*}{ Faye Abdellah Levels } & \multicolumn{3}{|c|}{ Pre $(n=800)$} & \multicolumn{3}{|c|}{ Post $(\mathrm{n}=\mathbf{8 0 0})$} & \multirow[b]{2}{*}{$\begin{array}{l}\text { Chi-square } \\
\text { t \%p-value }\end{array}$} \\
\hline & $\begin{array}{l}\text { Poor No } \\
(\%)\end{array}$ & $\begin{array}{l}\text { Average } \\
\text { No }(\%) \\
\end{array}$ & $\begin{array}{l}\text { V. Good } \\
\text { No (\%) } \\
\end{array}$ & $\begin{array}{l}\text { Poor No } \\
(\%)\end{array}$ & $\begin{array}{l}\text { Average } \\
\text { No (\%) } \\
\end{array}$ & $\begin{array}{l}\text { V. Good } \\
\text { No (\%) }\end{array}$ & \\
\hline $\begin{array}{l}\text { Level 1: Basic Care Needs (\#1-4) } \\
\text { Knowledge about head lice } \\
\text { Morphology of lice } \\
\text { Mode of transmission Clinical manifestation- Way of } \\
\text { diagnosis } \\
\text { Control Measures } \\
\text { Good hygiene and physical comfort } \\
\text { Prevention measures Interaction with other children. } \\
X \pm S D\end{array}$ & $(61.0)$ & $49.7 \pm 3.8$ & $(8.2)$ & $(23.4)$ & (16.6) & $(60.0)$ & $\mathrm{p}<0.001$ \\
\hline $\begin{array}{l}\text { Level 2- Sustenal Care Environmental sanitation. Proper } \\
\text { nutrition and fluids Hair Care -Control Measures } \\
X \pm S D\end{array}$ & $\begin{array}{l}177 \\
(22.1)\end{array}$ & $\begin{array}{l}535 \\
(66.9) \\
\mathbf{6 1 . 0} \pm \mathbf{4 . 9}\end{array}$ & $\begin{array}{l}88 \\
(11.0)\end{array}$ & $\begin{array}{l}33 \\
(4.1)\end{array}$ & $\begin{array}{l}144 \\
(18.0) \\
\mathbf{8 1 . 0} \pm \mathbf{7 . 4}\end{array}$ & $\begin{array}{l}623 \\
(77.9)\end{array}$ & $\mathrm{p}<0.001$ \\
\hline $\begin{array}{l}\text { Level 3- Remedial Care } \\
\text { Emotional Problems solving } \\
\text { as social stigma of head lice }\end{array}$ & 224 & 135 & 441 & 15 & 23 & 762 & $\mathrm{p}<0.001$ \\
\hline $\begin{array}{l}\text { Facilitate effective communication } \\
\text { Attend at school regularly Receive treatment - Develop a } \\
\text { trusting and therapeutic relationship } \\
\boldsymbol{X} \pm \boldsymbol{S D}\end{array}$ & $(28.0)$ & $(16.9)$ & $(55.1)$ & $(1.8)$ & $(2.9)$ & $(95.3)$ & \\
\hline $\begin{array}{l}\text { Level 4- Restorative Care Resolving problems arising from } \\
\text { illness. Follow up } \\
X \pm S D\end{array}$ & $\begin{array}{l}320 \\
(40.0)\end{array}$ & $\begin{array}{l}112 \\
(14.0) \\
\mathbf{6 3 . 9 \pm} \mathbf{1 . 8}\end{array}$ & $\begin{array}{l}368 \\
(46.0)\end{array}$ & $\begin{array}{l}130 \\
(16.2)\end{array}$ & $\begin{array}{l}182 \\
(22.8) \\
\mathbf{7 3 . 9} \pm \mathbf{2 . 1}\end{array}$ & $\begin{array}{l}488 \\
(61.0)\end{array}$ & $\mathrm{P}>0.05$ \\
\hline
\end{tabular}

Table (4) deliver the effect of the of Faye Abdellah Model on improving the students and their mothers, it is evident that there was highly significant statistically significant differences $(p<0.001)$ pre/post intervention concerning all levels of the model except restorative care level. In the interim concerning basic needs, The Mean X + SD show improvement from $49.7+3.8$ to $71.7+1.9$ pre/post intervention. Moreover only $(11.0 \%)$ of students got very good pre intervention as compared to $(77.9 \%)$ post intervention. Also (95.3\%) got high level in remedial care post intervention as compared to $(55.1 \%)$ pre intervention.

Table 5. Distribution of School Students and Their Mothers Score of State Self-Esteem Scale about Head Lice Social Stigma pre/post application of Scale.

\begin{tabular}{|c|c|c|c|c|}
\hline \multirow{2}{*}{ Scale Questions } & \multicolumn{2}{|c|}{ Egypt $\mathbf{N}=\mathbf{8 0 0}$} & \multicolumn{2}{|c|}{ Saudia Arabia $\mathbf{N}=\mathbf{8 0 0}$} \\
\hline & Before & After & Before & After \\
\hline I feel confident about my abilities. & 2 & 5 & 3 & 5 \\
\hline I am worried about whether I am regarded as a success or failure. (R) & 3 & 5 & 3 & 5 \\
\hline I feel satisfied with the way my body looks right now & 3 & 5 & 4 & 5 \\
\hline I feel frustrated or rattled about my performance. (R) & 5 & 3 & 5 & 2 \\
\hline I feel that I am having trouble understanding things that I read. (R) & 5 & 2 & 5 & 1 \\
\hline
\end{tabular}




\begin{tabular}{|c|c|c|c|c|}
\hline \multirow{2}{*}{ Scale Questions } & \multicolumn{2}{|c|}{ Egypt $N=800$} & \multicolumn{2}{|c|}{ Saudia Arabia $\mathbf{N}=\mathbf{8 0 0}$} \\
\hline & Before & After & Before & After \\
\hline I feel that others respect and admire me & 2 & 5 & 3 & 5 \\
\hline I am dissatisfied with my weight. (R) & 5 & 3 & 5 & 1 \\
\hline I feel self-conscious. (R) & 3 & 5 & 3 & 5 \\
\hline I feel as smart as others & 4 & 5 & 3 & 5 \\
\hline I feel displeased with myself. (R) & 5 & 2 & 5 & 1 \\
\hline I feel good about myself & 3 & 5 & 3 & 5 \\
\hline I am pleased with my appearance right now & 3 & 5 & 4 & 5 \\
\hline I am worried about what other people think of me. (R) & 5 & 2 & 5 & 1 \\
\hline I feel confident that I understand things & 3 & 5 & 3 & 5 \\
\hline I feel inferior to others at this moment. (R) & 3 & 5 & 4 & 5 \\
\hline I feel unattractive. (R) & 2 & 5 & 2 & 5 \\
\hline I feel concerned about the impression I am making. (R) & 3 & 5 & 3 & 5 \\
\hline I feel that I have less scholastic ability right now than others. (R) & 5 & 2 & 5 & 3 \\
\hline I feel like I'm not doing well. (R) & 5 & 3 & 5 & 2 \\
\hline I am worried about looking foolish. (R) & 5 & 2 & 5 & 2 \\
\hline
\end{tabular}

Table (5) mirror the effect of scale in banishing social stigma and civilizing the wellbeing of students and their mothers post application of Faye Abdellah Model. The students were same in both setting concerning improving their worried about a success or failure. (R), post intervention. They became more confident, satisfied with body looks, feel respected and smart, no frustration, doing well and high scholastic ability in a right way.

Table 6. Relation Between Students Aged group, Mayonnaise and Licid Shampoo Application in Both Settings.

\begin{tabular}{|c|c|c|c|c|c|c|c|c|c|c|c|c|c|c|c|c|}
\hline \multirow{4}{*}{$\begin{array}{l}\text { Age group (in } \\
\text { years) }\end{array}$} & \multicolumn{6}{|c|}{ Egypt } & \multirow{4}{*}{ Total } & & & \multirow{4}{*}{ Total } & \\
\hline & \multicolumn{6}{|c|}{$\begin{array}{l}N=\text { Mayonnasie Group }=400 \% \text { Licid } \\
\text { Group }=400\end{array}$} & & & \multicolumn{6}{|c|}{$\begin{array}{l}\text { Kingdom of Saudia Arabia } \\
\text { N= Mayonnasie Group }=\mathbf{4 0 0} \% \text { Licid Group }=400\end{array}$} & & \\
\hline & \multicolumn{2}{|c|}{$\begin{array}{l}\text { 6-8 years } \\
(\mathrm{n}=211)\end{array}$} & \multicolumn{2}{|c|}{$\begin{array}{l}\text { 8-10 years } \\
(\mathrm{n}=133)\end{array}$} & \multicolumn{2}{|c|}{$\begin{array}{l}\geq 12 \text { years } \\
(n=56)\end{array}$} & & & \multicolumn{2}{|c|}{$\begin{array}{l}\text { 6-8 years } \\
(n=134)\end{array}$} & \multicolumn{2}{|c|}{$\begin{array}{l}\text { 8-10 years } \\
(\mathrm{n}=220)\end{array}$} & \multicolumn{2}{|c|}{$\begin{array}{l}\geq 12 \text { years } \\
(n=46)\end{array}$} & & \\
\hline & No & $(\%)$ & No & $(\%)$ & No & $(\%)$ & & & No & $(\%)$ & \begin{tabular}{|l|l|} 
No \\
\end{tabular} & $(\%)$ & No & $(\%)$ & & \\
\hline Mayonnaise & \multicolumn{8}{|c|}{ Group 1} & \multicolumn{8}{|c|}{ Group 1} \\
\hline $\begin{array}{l}\text { Between 6-7 } \\
\text { Days }\end{array}$ & 146 & $(69.2)$ & 85 & (63.9) & 37 & $(66.1)$ & 268 & $(67.0)$ & 100 & (74.6) & 143 & $(65.0)$ & 29 & $(63.0)$ & 272 & $(68.0)$ \\
\hline From 7 to 8 & 65 & $(30.8)$ & 48 & $(36.1)$ & 19 & (33.9) & 132 & $(33.0)$ & 34 & $(25.4)$ & 77 & (35.0) & 17 & $(37.0)$ & 128 & (32.0) \\
\hline 8 and more & 0 & $(0.00)$ & 0 & $(0.00)$ & 0 & $(0.00)$ & 0 & $(0.00)$ & 0 & $(0.00)$ & 0 & $(0.00)$ & 0 & $(0.00)$ & 0 & $(0.00)$ \\
\hline $\begin{array}{l}\text { Licid } \\
\text { Shampoo }\end{array}$ & \multicolumn{8}{|c|}{ Group 2} & \multicolumn{8}{|c|}{ Group 2} \\
\hline $\begin{array}{l}\text { Between 6-7 } \\
\text { Days }\end{array}$ & 46 & $(21.8)$ & 38 & (28.6) & 15 & $(26.8)$ & 99 & $(24.8)$ & 35 & $(26.1)$ & 49 & $(22.3)$ & 6 & $(13.0)$ & 90 & (22.5) \\
\hline From 7 to 8 & 39 & $(18.5)$ & 26 & (19.5) & 8 & (14.3) & 73 & $(18.2)$ & 30 & $(22.4)$ & 55 & $(25.0)$ & 14 & $(30.5)$ & 99 & (24.8) \\
\hline 8 and more & 126 & (59.7) & 69 & (51.9) & 33 & $(58.9)$ & 228 & $(57.0)$ & 69 & $(51.5)$ & 116 & $(52.7)$ & 26 & $(56.5)$ & 211 & (52.7) \\
\hline
\end{tabular}

It is evident from table (6) that mayonnaise effect in banishing head lice was earlier among students in both settings, none of girls stayed infected beyond 8 and more days. In Egypt, all students aged groups recovered from infection between 6 to 7 days by proportion more than two third (69.2\%), (63.9\%), (66.1\%) respectively. In Saudia Arabia, the same surprising results were confirmed the quantity were $(74.6 \%),(65.0 \%)(63.0 \%)$ respectively. By the way the application of licid shampoo display longer time, where majority of students in both settings group convalesced after 8 and more days the percentage was more than half as total in Egypt (58.9\%) and Saudia Arabia (52.7\%).

\section{Discussion}

Social stigma of head lice creates a barrier for school students and their mothers who are embarrassed about having an infestation that it stops them from seeking the right treatment and advice. The present study was carried out on
1600 school students and their mothers to monitor the effects of Faye Abdellah model on banishing social stigma of head lice among school students and monitor its effect on students and their mothers health status and self-esteem.

The researchers founded in Egypt, the total prevalence ratio was $20.8 \%$ and $17.8 \%$ in Kingdom of Saudia Arabia. Furthermore the study results in table (1) revealed that the prevalence of head lice among study students girls was common in Egypt in Grade Level 1st \& 2nd and their aged ranged from 6 to 8 years where more than half $(52.75 \%)$ of students were infected. In Saudia Arabia the prevalence was common among students in Grade Level 3rd\% 4th and aged ranged from 8 to 10 years, more than half $(55.0 \%)$ of students were infected. Besides, about (43.25\%) of the families in Saudia Arabia having more than 5 children as compared to $(10.62 \%)$ in Egypt. It could be growing community without family spacing. This in agreement with [22] [23] who reported that the peak incidence of lice infection is between 5 to 13 years of age. The prevalence of 
the present study was near from [24] who found a hyperendemic prevalence of 20-40\% in Australian schools noting that infestation affects both sexes and all social classes and in the less proportion with [25] who mentioned in Brazil, studies indicate that the disease affects all age groups in poor communities, and the prevalence can reach $40 \%$ of the general population [26]. In the present study, all the sample were girls, this in harmonious with [27] who reported that female children are often the most affected, and the number of cases varies with the time of year. Mothers education and employment or not status was not significantly associated with lice infestation.

The findings of the current study as displayed in table (2) showed that the hair length among students in Saudia Arabia more longer as compared to students in Egypt, where more than two third $(62.7 \%)$ of them, from 6-8 years their hair length was more than $20 \mathrm{~cm}$ as compared to (20.2\%) in Egypt. The repeated infections for 2 to 3 times was common (78.2\%). In Egypt among youngest students from 6 to 8 years and $(91.1 \%)$ among $\geq 12$ years students. In Saudia Arabia, the recurrence of infection from 2 to 3 times common to students aged from 8to 10years, and $\geq 12$ years where $(55.0 \%)$ and (75.0) were infected respectively. The risk factors was few among $\geq 12$ years students in both settings. The table convey that mothers in both settings used Licid Lotion as a treatment to overcome the head lice, but in Saudia Arabia none of the mothers used Kerosene as head lice treatment as compared to (53.3\%) (47.8\%) (22.3\%) respectively in Egypt. The mothers don't know it. This could be a habitat in Egypt. This results in the same stream with [28] who recommended that all socioeconomic groups are affected, and infestations are seen throughout the world. Head lice infestation is not significantly influenced by hair length or by frequent brushing or shampooing. On the other hand [29] stated that head lice transmit from person to person directly during children's play or indirect through contact with lice carrying such as brushes, combs, clothing and towels. In addition to [30] who stated that many factors such as poor hygiene, socioeconomic status, lack of medical treatment and resistance to the treatment leads to increase the prevalence of head lice. There is evidence showing that routine class or school-wide screening reduces lice infestation rates. The results of the current study with the same direction with [31] who revealed that the highest percentage of infestation was among children with a past history of infestation (57.4\%) and this was a statistically significant finding. But longer hair length, lack of bathing facilities, low frequency of hair-washing and bathing, and sharing of articles (e.g. combs, scarves) were significantly associated with infestation $(\mathrm{P}<0.001)$. In addition, [32] acknowledged that millions of dollars are spent annually on pediculicides, lice combs, physician visits, and parental time away from work. In an effort to find an easy, effective, and safe treatment, a variety of alternative therapies as occlusive agents such as oil-based and grease-based products, electric combs, herbal shampoos and enzyme solutions, have been attempted by parents. The researchers founded that there is insufficient scientific evidence regarding the effectiveness of these alternative treatments, and all have an associated cost. It is evident from table (6) that mayonnaise effect in banishing head lice was earlier among students girls in both settings, none of students stayed infected beyond 8 and more days. In Egypt, all students aged groups of girls recovered from infection between 6 to 7 days by proportion more than two third (69.2\%), (63.9\%), (66.1\%) respectively. In Saudia Arabia, the same surprising results were confirmed the quantity were $(74.6 \%),(65.0 \%)(63.0 \%)$ respectively. By the way the application of licid shampoo display longer time, where majority of students in both settings group convalesced after 8 and more days the percentage was more than half as total in Egypt $(58.9 \%)$ and Saudia Arabia $(52.7 \%)$. Indeed this study is an attempt to solve our communities problem, mayonnaise is cheap, not dangerous, people eating it and easily used. In (2010) [33] CDC recommended that no scientific studies that prove the effectiveness of mayonnaise as a treatment for head lice, but there are many mothers who have been using it for years and are very satisfied with the effectiveness of this home remedy against adult head lice.

The present study indicate that prevalence of head lice as problem was alarming in both settings as shown in table (3) and table (4) that reproduces the effects of pre/post application of Faye Abdellah Model on students and their mothers in terms of knowledge and care. There was highly significant statistically significant differences $(p<0.001)$ concerning knowledge of the sample about head lice pre/post application of the model in both settings, regarding all levels of model intervention except restorative care level was insignificant $(\mathrm{P}>0.05)$. This reflect that instead of success of model, still there is a need for follow up in schools. The researchers advised the team of nurses to continue by the same manner after they have finished. They felt unethically to leave our heart and lovely students without attention. This in settlement of The CDC (2010) [33], it endorsed that the school nurse is the key health professional to provide education and anticipatory guidance to the school community regarding best practice guidance in the management of head lice. The school nurse's goals are to facilitate an accurate assessment of the problem, contain infestation, provide appropriate health information for treatment and prevention, prevent overexposure to potentially hazardous chemicals, and minimize school absence. There is discussion in the scientific community on the best way to control head lice infestation in school children. In Egypt, there was a school nurses but they are in need to update their knowledge and attend training program. The situation was poor in Saudia Arabia, where no school nurses available and social worker appropriated their roles. Faye Abdellah mentioned that nursing is a helping profession, a comprehensive service to meet patient's needs, increases or restores self-help ability through uses 21 problems to guide nursing care [34].

Concerning banishing social stigma, table (5) exposed the effect of scale in and civilizing the wellbeing of students and their parents post application of Faye Abdellah Model. The 
students became more confident, satisfied with body looks, sense respected and smart, no frustration, doing well and high scholastic ability in a right way. The researchers explained to subjects that head lice infestations not related to personal or environmental cleanliness, nor to poor living conditions. Head lice prefer children with good hygiene and grooming habits. [35] declared that social stigma attached to lice infestations make managing fears as important as treatment. Lice infections are often misdiagnosed, and parents embrace all type of implausible or ineffective treatment.

Finally, [36] conveyed that there are numerous treatment options for lice ranging in efficacy, safety profile, and tolerability. It is imperative that, when treating lice, providers consider these factors as well as regional resistance rates to particular therapies. Further research is needed to confirm the efficacy of newer therapies compared with established drugs and protocols to ensure that patients are treated with the safest and most efficacious agent possible.

\section{Conclusion}

For centuries hair lice have been involved in the day to day lives of most families worldwide. It generate disproportionate brouhaha, and social stigma is far worse than their bite. No student should be accused for having lice, only blamed for keeping them. The current study is a trial to banishing the terrible problem but not success without hands-on of students, mothers, school nurses and community. Society should include in "planning for optimum health on local, state, and international levels."

School nurses are uniquely positioned to advance the academic achievement of students by protecting their health and safety. Prevention, early recognition, and treatment of child maltreatment are critical to the physical/emotional wellbeing of students and, therefore, their academic success. Additionally, school nurses serve as a resource to faculty and staff in the recognition and reporting of child maltreatment. National Association of School Nurses (NASN, 2015).

\section{Recommendation}

Abdellah theory focus on nursing service to the individual so the present study recommended that: Knowledge is power and teaching mothers and students about head lice myths and facts is key to demystifying the stigma. If pediatricians and school officials react calmly, mothers can focus on treatment without the tragedy. There is a need for a consistent, integrated, rational approach to the prevention and control of head louse infection with high quality scientific research for the production of authoritative, evidence-based policies. Each school should have a head lice school policy in place that describes procedures that will be followed to identify head lice, notify mothers, teachers and other school personnel, minimize transfer of head lice and how and when to do follow-up after treatment. Using of mayonnaise, cheap, no chemical effects and easily used.

\section{Acknowledgements}

We would like to express our deep gratitude and gratefulness to the Schools principles, schools social workers and school nurses, and school teachers for their approval and cooperation throughout the duration of the study. A lot of thanks for mothers and students at both Country for their agreement and cooperation to participate in the study. My deep appreciation to Dr: Ahmed Atef and Norah Al Sadhan for their kind help and great cooperation throughout the study.

\section{References}

[1] Drummond Linda. (2014). Head lice: the social stigma $\subset$ Kid spot, All Rights Reserved. http://www.kidspot.com.au/schoolzone/Head-lice-Head-licethe-social-stigma+4459+318+article.htm(2016).

[2] Brenda Major, Laurie T. O'Brien. (2005). "The Social Psychology of Stigma", Annual Review of Psychology 56 (1): 393-421, doi: 10.1146/annurev.psych.56.091103.070137.

[3] Cox, William T. L.; Abramson, Lyn Y.; Devine, Patricia G.; Hollon, Steven D. (2012). "Stereotypes, Prejudice, and Depression: The Integrated Perspective". Perspectives on Psychological Science 7 (5): 427-49. doi: $10.1177 / 1745691612455204$. line feed character in journal= at position 15 .

[4] Hodgdon HE, Yoon KS, Previte DJ, et al. (2010). Determination of knockdown resistance allele frequencies in global human head louse populations using the serial invasive signal amplification reaction. Pest Manag Sci.; 66(9): 1031-1040.

[5] Meinking T, Taplin D, Vicaria M. Infestations. In: Schachner LA, Hansen RC, eds. (2011). Pediatric Dermatology, 4th ed. Mosby Elsevier: 1535-1583.

[6] Parison J, Canyon DV. (2010). Head lice and the impact of knowledge, attitudes and practices-a social science overview. In: Management and Control of Head Lice Infestations. UNI-MED, Bremen, Germany, 103-109.

[7] Gordon, S. (2007). Shared Vulnerability: A theory of caring for children with persistent head lice. The Journal of School Nursing. $23 \quad$ (5) 283-292. doi: $10.1177 / 10598405070230050701$.

[8] Centers for Disease Control and Prevention. (2015). Parasites: lice: head lice. Available at: www.cdc.gov/parasites/lice/ head/. Accessed February 26.

[9] American Academy of Pediatrics. (2013). Health issues. Signs of lice. HealthyChildren.org Web site. www.healthychildren.org/english/health-issues/conditions/frominsects-animals/pages/signs-of-lice.aspx.

[10] Frankowski, B. L, \%Bocchini, J. A. (2010). Clinical ReportHead Lice. Pediatrics. 126(2) 392-403. Retrieved from http://pediatrics.aappublications.org/cgi/content/abstract/126/2 /392 doi: 10.1542/peds.2010-1308.

[11] Bosely HA, El-Alfy NM. (2011). Head lice infestations (Anoplura: Pediculidae) in Saudi and non-Saudi school-aged children. Department of Biology, Faculty of Science, Jazan University, Saudi Arabia. J Egypt Soc Parasitol [41(1): 131140] (PMID: 21634249)]. 
[12] AL-Megrin Wafa A. I. (2015). Assessment of the Prevalence of Pediculosis capitis among Primary School Girls in Riyadh, Saudi Arabia. Research Journal of Environmental Sciences, 9: 193-199.

[13] Mostafa F F, Hassan A A, Soliman M I, Nassar A, Hassan R. (2011). Prevalence of skin diseases among infants and children in Al Sharqia Governorate, Egypt. Faculty of Medicine, Zagazig University, Egypt Egyptian Dermatology Online Journal 8(1).

[14] El Sahn, AA., MH. Hassan, EM. Ftohy, NE. Abou-El Ela, SM. Eassa, (2000). Parasitic infections and maternal awareness of preschool children in Karmouz district, Alexandria. J Egypt Public Health Assoc, 75: 1-29.

[15] El-Khawaga, G., F. Abdel-Wahab, W. Mohamed, (2012). Prevalence Of Pediculosis Capitis Among Primary female School Students In An Egyptian Village. The Egyptian Journal of Community Medicine, 30(4).

[16] Alice Petiprin. (2015). Nursing-Theory. http://www.nursing-theory.org/nursing-theorists/FayeAbdellah.php.

[17] Abdellah, F. G., \% Levine, E. (1994). Preparing nursing research for the 21st century. New York: Springer. 21 Nursing Problems Theory - Nurseslabs.html (C) 2016.

[18] Yoon, K. S., Clark, J. M., et al. (2015). Lice in at least 25 states show resistance to common treatments. Presented at American Chemical Society. http://www.smithsonianmag.com/sciencenature/ice-can-resistdrugs-have-infested-half-states-us-180956308/?no-ist; Press

[19] Up To Date. (2016). Terms of Use, Kingdom of Saudia Arabia, Ministry of Health-Wolters Kluwer (C2016 http://www.uptodate.com/home/terms-use.

[20] Meinking, T. L., Villar, M. E., Vicaria, M., Eyerdam, D. H., Paquet, D., Mertz-Rivera, K., Reyna, S. (2010). The clinical trials supporting

[21] Heatherton, T. F., \%Polivy, J. (1991). Development and validation of a scale for measuring state self-esteem. Journal of Personality and Social Psychology, 60, 895-910.

[22] Motovali-Emami, M., Aflatoonian, M. R., Fekri, A., \%Yazdi, M. (2008). Epidemiological aspects of pediculosis capitis and treatment evaluation in primary school children in Iran. Pakistan Journal of Biological Sciences 11(2): 260-4.

[23] Hodjati, M. H., Mousavi, N., \%Mousavi, M. (2008). Head lice infestation in schoolchildren of a low socio-economy area of Tabriz city, Iran. African Journal of Biotechnology 7(13): 2292-2294.

[24] Canyon, D. V., \%Speare, R. (2007). Do head lice spread in swimming pools? International Journal of Dermatology, 46, 1211-1213.

[25] Heukelbach J, Wilcke T, Winter B, Feldmeier H. (2005). Epidemiology and morbidity of scabies and pediculosis capitis in resource-poor communities in Brazil. Br J Dermatol; 153: 150-6.
[26] Heukelbach J et al. (2008). A highly efficacious pediculicide based on dimeticone: Randomized observer blinded comparative trial, BMC Infect. Dis. 2008, 8: 115 doi: 10.1186/1471-2334-8-115.

[27] Feldmeier H. (2012). Pediculosis capitis: new insights into epidemiology, diagnosis and treatment. Eur J Clin Microbiol Infect Dis 31(9): 2105-2110. doi: 10.1007/s10096-012-15750 .

[28] Centers for Disease Control and Prevention. (2015). Parasites: lice: head lice. Available at: www.cdc.gov/parasites/lice/ head/. Accessed February 26.

[29] AL-Shawa, R. M. (2008). Pediculus capitis, infestation according to sex and social factors in Gaza Governorate. The Islamic University Journal (Series of Natural Studies and Engineering) 16(1): 75-83.

[30] Boshra Vahabi, Ahmad Vahabi, Alireza Gharib, Mahnaz Sayyadi, Sirvan Sayyad. (2013). Prevalence of head louse infestations and factors affecting the rate of infestation among primary schoolchildren in Paveh City, Kermanshah Province, Iran in the years 2009 to 2010. Life Science Journal; 10(12s).

[31] Bashtawy M. A and Hasna F. (2012). Pediculosis capitis among primary-school children in Mafraq Governorate, Jordan. Eastern Mediterranean Health Journal EMHJ. Vol. 18 No. 1.

[32] Frankowski BL, Bocchini JA Jr; Council on School Health and Committee on Infectious Diseases. Head lice. Pediatrics. (2010); 126 (2): 392-403. Gordon SC. (2007): Shared vulnerability: a theory of caring for children with persistent head lice. J Sch Nurs.; 23(5): 283-292.

[33] Centers for Disease Control and Prevention. (2010). Head lice information for schools. Retrieved from http://www.cdc.gov/parasites/lice/head/index.html.

[34] Eichelberger, L. W. (2011). Pioneering nursing theory on the world wide web - Evolution of nursing theory on the internet. In Sitzman, K., and Eichelberger, L. W., Understanding the work of nurse theorists: A creative beginning. 2nd Edition. pp. 217-226. Sudbury.

[35] Goldstein AO, Goldstein BG. (2009). Head lice (Pediculosis capitis) In: Up To Date, Basow, DS (Ed), Up To Date, Waltham, MA, benzyl alcohol lotion 5\% (Ulefsia ): A safe and effective topical treatment for head lice (Pediculosis humanus capitis). Pediatric Dermatology, 27, 19-24.

[36] Wadowski Lisa, Balasuriya, Lily, Price N. Harper, O'Haver, Judith. (2015). Lice update: New solutions to an old problem Clinics in Dermatology Pediatric Dermatology: Part II Volume 33, Issue 3, Pages 347-354.

[37] National Association of School Nurses (NASN). (2015) Position Statements Resolutions and Consensus Statements Joint Statements. http://www.nasn.org/- 8484 Georgia Avenue Suite 420 Silver Spring, Maryland 209101 - 240 - 821 1130https://www.nasn.org/portals/0/binder_papers_reports.pd. 